\title{
The Excentric Film Project of Gotot Prakosa
}

\author{
Dylan M. Fagan \\ University of California, Berkeley, CA, USA \\ dylan.fagan@berkeley.edu
}

\begin{abstract}
This article outlines the film practice of Gotot Prakosa (1955-2015), which he called film pinggiran (film of the edges, excentric film), and its relationships with the hegemony exerted by the Indonesian New Order government in the 1970s and 1980s. By examining Gotot's film works and extensive reflections on film-making, this article elucidates the dual characteristic of film pinggiran as a spatial and theoretical principle that orientates an excentric drive in the production and circulation of film. The article suggests that the film practice realized both an analysis of, and contradiction to, New Order mass media infrastructures and superstructures, thus engendering an ideological strike on the reproduction of the hegemony of the New Order. Film pinggiran thus does not necessarily 'push the boundary' further away; instead, it makes the edge the manifest content itself.
\end{abstract}

\section{Keywords}

Gotot Prakosa - film - the New Order - ideology - infrastructure

This article situates the contested co-presence of the hegemony exerted by the Indonesian New Order government in the 1970s and 1980s and the film practice realized in the same period by Gotot Prakosa (1955-2015), which he called film pinggiran (film of the edges, excentric film). ${ }^{1}$ While the foundational texts

1 Pinggir is the edge, fringe, rim, outside, or limit of space between two other spaces, often a road or city. Film pinggiran connotes both a genre descriptor, which can be translated as 'marginal film' or 'film of the edges', and a prescriptive film practice, which can be translated as 'excentric film'. Excentric indicates a field whose axis and points of support are not centrally placed and do not pass through the centre. 
of Indonesian film studies have underscored the importance of the New Order ideology for film in this period, these studies have focused on its impact on films produced for, and screened in, commercial cinemas (Heider 1991; Sen 1994; Said 1991). This article, in turn, outlines the strategy and tactics of film pinggiran, whereby films were explicitly not made for, or screened at, commercial localities. In particular, the article examines how this film practice realized both an analysis of, and contradiction to, New Order mass media infrastructures and superstructures. By examining Gotot's film works and extensive reflections on film-making, this article elucidates how the dual characteristic of film pinggiran - as a spatial and theoretical principle that orientates an excentric drive in the production and circulation of film-engendered an ideological strike on the reproduction of the hegemony of the New Order.

\section{$\mathbf{1}$ \\ The Centres and Edges of Film Circulation in the Mid New Order Period $\left(1975^{-1985}\right)$}

Gotot characterized his film project of film pinggiran as a dual organization (Prakosa 1997). On the one hand, it produced marginal filmic forms and notions. On the other hand, it displaced the screening site of films out of the infrastructures controlled by the government and into liminal and unconventional places. This generated an engagement with film which facilitated modes of thinking and sociality where the New Order government's bridling ideology was cross-examined, if not foiled. In order to contextualize the particular characteristics of this dissentient film practice, this article first clarifies the conjuncture of governmental infrastructures within which Gotot worked, specifically Taman Ismail Marzuki (тім, Ismail Marzuki Park) and the national governmental television network Televisi Republik Indonesia (TVRI, Television of the Republic of Indonesia).

Taman Ismail Marzuki was established in 1968 by Ali Sadikin, the Governor of Jakarta, to create a state space for art that also included an art institution, Lembaga Pendidikan Kesenian Jakarta (LPKJ, Jakarta Institute of Art Education). ${ }^{2}$ The construction of Taman Ismail Marzuki and LPKJ indicated the aim of the New Order government to organize a society that included artistic production, but at a site within the visibility of the state. In the middle of the 1970s, the name of LPKJ was changed to Institut Kesenian Jakarta (I KJ, Jakarta

2 'Biography Ali Sadikin'. http://info-biografi.blogspot.com/2012/og/biografi-ali-sadikin.html (accessed 1-7-2020). 
Art Institute). While both lembaga and institut mean institute, the latter name mirrored the Institut Teknologi Bandung (гтв, Bandung Institute of Technology) in the city of Bandung, a centre of so-called modern scientific thinking.

Taman (of Taman Ismail Marzuki) is another term of governmental geography, but from an episteme predating lembaga and institut. Taman in Java is a name for a garden or park, but it is furthermore the space constituted by the sovereign ruler. In the tradition of hikayat literature, a taman is the site of civilized space as well as the sovereign's gaze and control (Robson 1969). A taman thus creates a social space at the same time as introducing control into that space. Taman Ismail Marzuki was thus a state 'garden' for artists, but situated within the visibility of the state; it constituted a field of possibility for artists as well as of their surveillance. Dr Salim Said, a chairman of the Arts Council of Jakarta, commemorating the first 25 years of this site of state geography, wrote:

The history of the Centre of Jakarta Art [Taman Ismail Marzuki] at its foundation is a history with two sides. There is the history of the creativity of artists and the public thought towards it, but at the same time, there is also the history of the attention of the Governor of the Jakarta Metropolitan Area towards art and the freedom of creativity. ${ }^{3}$

PADMODARMAYA 1994:18

Artistic production met the attention, awareness, and concern of the Indonesian state in TIM. This governmental attention animated the decamping, in both conceptual and geographical ways, of artists out from this centre of TIM and towards the pinggiran - the margins, limits, peripheries, edges, and exteriors.

Gotot entered the department of cinematography of $\mathrm{IKJ}$ as a student in 1975, not long after the department opened in 1971 (Prakosa 1997:3). For this first generation of IKJ cinematography students, a great deal of film activity entailed watching cinema in Kine Klub, a group pioneered by Gotot's primary film teacher and mentor, D.A. Peransi (Padmodarmaya 1994:100-7). This spectatorial activity occurred at the same time that many other Indonesian artists working at TIM and Ітв were gaining attention for producing their own formally and conceptually significant works in literary, sculptural, and fine-art media. This fundamental contrast with the other art forms induced three internally related consequences for Gotot and the first generation of film-

3 All translations in this article from Indonesian are the author's own. 
makers at IKJ. Firstly, this initial identity of 'lagging behind' the other arts generated an awareness of the possibility itself for a formal rebellion in film practice. For Gotot in 1975, there were few Indonesian cinema auteurs as supposed subjects of cinematic knowledge. Secondly, due to this 'immaturity' and the close proximity of the other art disciplines at TIM and I KJ, the early film production of Gotot was, from the beginning, an interdisciplinary art form. Thirdly, the identity of film as lacking a distinctive art practice conferred a formal lightness, as it did not inherit the weight (or richness) of a tradition like the other art forms. Gotot's experimental practice therefore did not bear the negative, formalist reflex of seeking to destroy the traditions and inherited forms as other artists did at that moment, most notably the Gerakan Seni Rupa Baru (New Art Movement) (Supangkat 1979). These conditions, converging with the governmental surveillance, animated the aim of film pinggiran for displacing film out of its habituated forms and norms.

Gotot began film-making at IKJ after he had already studied painting in Yogyakarta at the Sekolah Seni Rupa Indonesia (SSRI, Indonesian School of Fine Art). Already able to paint but unable to create films with a camera, his first films were created by collecting the film stock that his teacher at IKJ, Sjumandjaya, had thrown away. After cleaning it, Gotot painted directly onto the celluloid surface, creating the first ever animation works to be made with this technique in Indonesia (Prakosa 2012; 1990:25-31). When the prominent film scholars Arthur and Corrine Cantrills met Gotot and saw these films in Australia in 1990, they remarked that they looked like the films of American Stan Brakhage. Gotot responded that this might be true but that he had never seen the films nor had he known of the techniques of Brakhage when he made them (Prakosa 1990:26). It was instead his experience with painting, coupled with the scarcity and strict regulations surrounding the procurement of film stock at IKJ at the time, that had produced the conditions whereby his first experiment in film-making came from discarded film stock and thus 'looked like' the works of Brakhage.

After painting onto the recycled celluloid, Gotot worked with IKJ musicians to create a musical track for the films. Together, Gotot said that animation films produce visual rhythms; 'the concept of audio-visual should be turned around into visual-audio' (Prakosa 2010:124).

But while Gotot experimented with the relationship of sound and image, this practice did not emerge from a theoretical inquiry, but instead from the conditions of production, where he lacked easy access to fresh film stock and could not make music himself. For Gotot, film-making was from its origin necessarily an experiment with the formal separation of sound and visual images. 


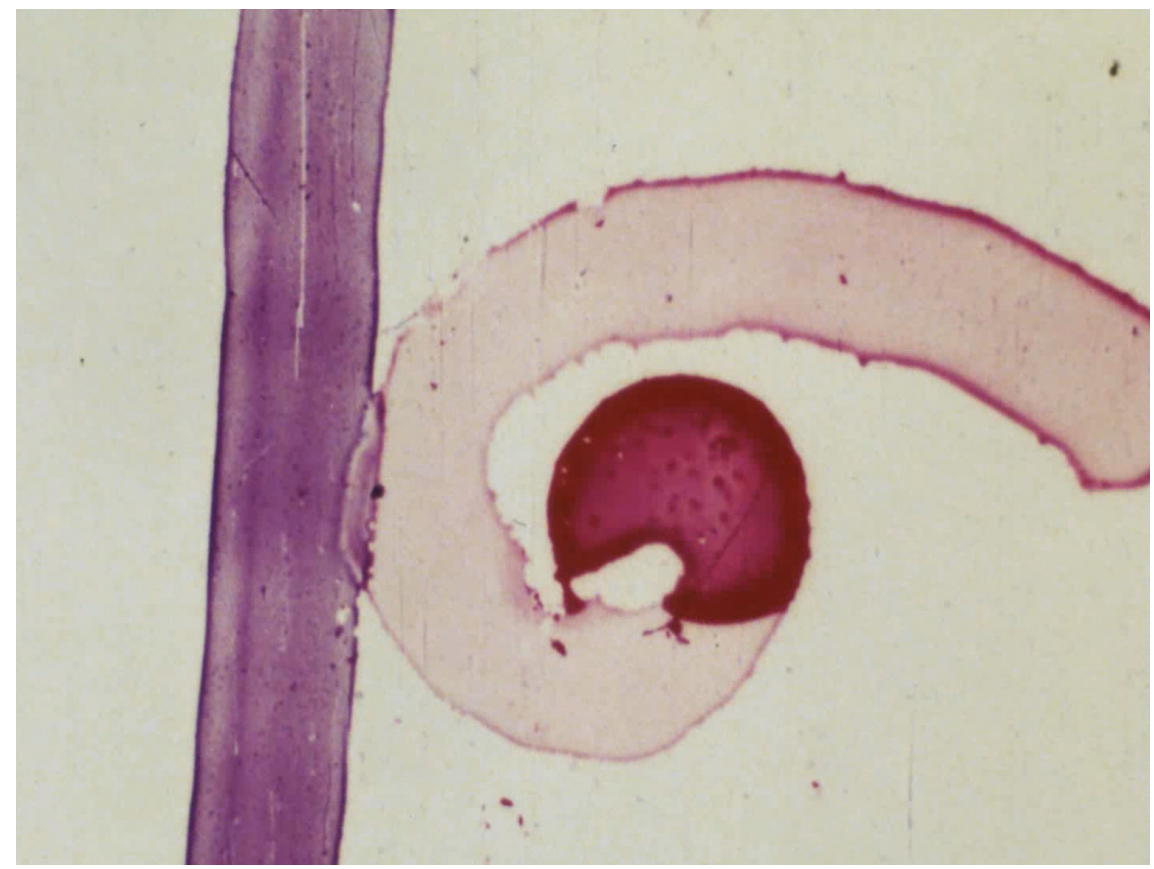

FIGURE 1 Impuls, Gotot Prakosa, 1976

His first animation films, Meta meta and Impuls (see Figures 1 and 2), both made in 1976, contain no visual signifiers with unequivocal corresponding visual signifieds. Instead, twittering globules appear, filled with bright primary colours and thickly painted outlines. Dots, coloured circles, and spirals appear momentarily before metamorphosing into other shapes and colours for two minutes. The music for Meta meta, made by Slamet Abdul Sjukur, is backed by a rapid drum beat and overlaid with a loop of arrhythmic, dissonant shrieks that repeats every six seconds. The shapes and the sounds together form no linear or diachronic narrative. Instead they are, as the titles suggest, a visual and sonic, if not cosmic, consideration of what is beyond the beyond. These first works evince an aesthetic project of the pinggiran that makes impossible any return to the habituated interpretative norms guiding cinema.

\section{The Cadastral Television}

At the same moment that these IKJ film students were experimenting with the film medium, the government of General Soeharto had also taken it up as the dominant medium for disseminating the New Order ideology (Van Heeren 


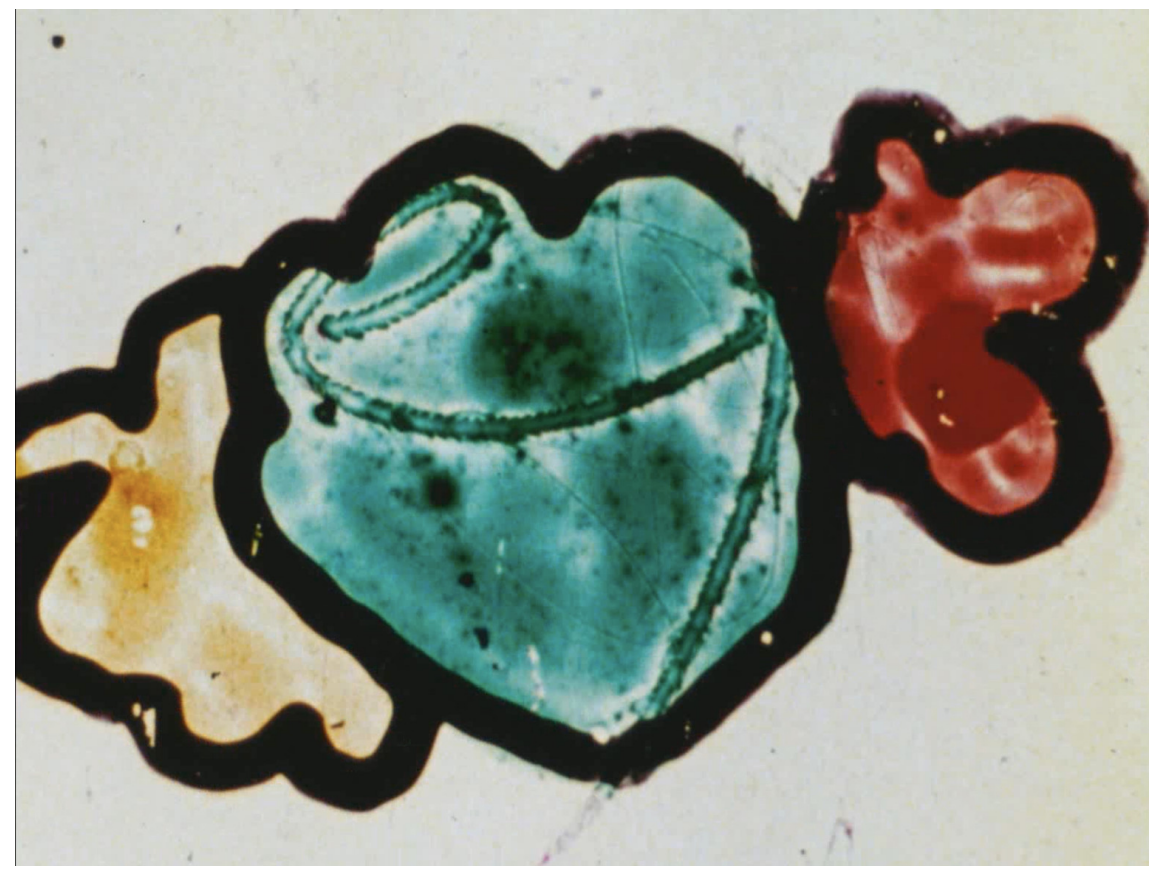

FIgURE 2 Meta meta, Gotot Prakosa, 1976

2012:91-4). Television in particular made the government's messages audible and visible to much of the population. The launch of the Palapa satellite in 1976 made the massive expansion of television in Indonesia possible and cemented the identity of television as the governmental language and apparatus of propaganda (Kitley 2000).

Furthermore, the naming of Palapa underlined how the government understood television as a state apparatus that would, like the military, unify the archipelagic territory of Indonesia. The name Palapa refers to the Sumpah Palapa (Palapa oath), in which Gajah Mada, a warrior minister of the Majapahit Empire, vowed that he would 'not eat the fruit of the Palapa until he had brought about the unity and oneness of the Majapahit Kingdom' (Barker 2005:703). The television formed a communicational architecture for the government of General Soeharto that mirrored the territorial unification brought about through the placement of the military in every territorial region of the nation (Mietzner 2006). The ideological knot of the military, television, and territorial unity was cinched at the origin of the governmental televisual imagination and strategy.

The launch of the Palapa satellite was itself not sufficient for ensuring the distribution of governmental propaganda through television. After the launch, 
the number of television sets dramatically increased, both provided for free by the government as well as through personal purchase (Kitley 2000:57). Since there was only one television channel, Televisi Republik Indonesia (TVRI), a television set was tantamount to a government mouthpiece; the television thus formed an ideological space controlled by the Indonesian government within each personal home that owned a television (Prakosa 2011:94-7; Dhakidae 2003:269-70). TVRI, like the creation of Taman Ismail Marzuki, evinced the governmental strategy of both centralizing and regulating the production and circulation of mass media. In a speech in 2011, Gotot Prakosa recalled television of this period by saying:

The Indonesian minister of information at that time was H. Harmoko, ${ }^{4}$ who made a very popular populist programme for TVRI named Klompencapir (the name used for a group of listeners, readers, and viewers), which was broadcast each week. Its approach was a form of propaganda, only showing the successful efforts of government programmes which were well nigh flawless and blemish-free. Likewise, the majority of the reports on the TVRI News consisted of the openings and inaugurations of factories, toll roads, or programmes set up by the government of Indonesia, and usually featured the minister responsible for the given programme. Indeed, these broadcasts could even be ordered by these ministers so that the factories, toll roads and programmes were seen by the president and ensure his approval. From these situations then arose the term ABs $^{5}$ (Asal Bapak Senang).

PRAKOSA 2011:96

Gotot thereby expressed the immense contradiction that was sensed through the presence of television. The daily depictions of the government opening factories and toll roads identified the televisual apparatus as the specific technology through which the ideology of the New Order materialized on a mass scale. But the exhibition of factories, bridges, and toll roads, supposedly attesting to the glory of development, led Gotot instead to a critical inquiry into

4 During student protests against the New Order in the 199os, students made a pun (plesetan) out of the minister's name: HAR (hari-hari) MO (omong) KO (kosong). 'Hari-hari omong kosong', which in context would translate to 'everyday bullshit'. Anonymous interview with Reformasi-era student activist.

5 Asal Bapak Senang literally means 'the source of a father's happiness', but it refers to a situation in which while the formality has been provided and the situation appears harmonious, this hides another reality. 
'development' and modern technology. His film practice repositioned both the form and content of the TVRI films that glorified construction and development. The next two sections of this article elucidate how Gotot, by convening film screenings in irregular and unregulated spaces and by producing films that satirized the content of TVRI, determinately contradicted the regularized seriality of space and time that the infrastructure of TVRI modulated into the New Order.

\section{The Several Lineages of Film Pendek}

The conjuncture of the freedoms and surveillance of TIM, the meteoric rise of TVRI propaganda, and the 'pre-mature' identity of film animated the emergence of the practices of film pinggiran. In this convergence, Gotot worked in the film pendek (short film) genre for his earliest cinematic compositions (Prakosa 1997:1-3). As film pendek possessed a well-known statist lineage, the claim by Gotot to the film pendek moniker was motivated in part by the aforementioned surveillance of the artists of IKJ and TIM (Prakosa, Atmowiloto and Rendra 2006). Stitching himself into the tradition of film pendek afforded Gotot an appearance of neutrality, which he used for reconstituting the form of film pendek in ways antithetical to its statist traditions.

The film pendek form was used by Indonesian governments from the earliest moments of the Republic of Indonesia and its use continued throughout the New Order. The consecration of the audio-visual apparatus as an ideological tool used by the governing sovereign ruler emerged during the World War II Japanese occupation in what later became the Republic of Indonesia (Biran 2009). Usmar Ismail, the now-celebrated Indonesian film-maker of the early independence period, wrote that he came to understand cinema as a tool that distributed normative messages to society during the Japanese occupation:

The arrival of the Japanese film instructors in Indonesia created an awareness of the function of film. Film-making needed to be developed in an effort to build a national film industry [...] It was only at the beginning of the Japanese period that people became aware of the function of film as a tool for social communication [...] In films, the Indonesian language is used formally and thus draws us closer to a feeling of nationalism.

BIRAN 2009:348

The independence of Indonesia did not erode the relationship of the moving image as a medium for circulating the nationalist articulations. The Pusat 
Produksi Film Indonesia (PPFN, Indonesian Film Production Centre) and the Departemen Penerangan (Department of Information) produced film pendek in the 1950s and 1960s known as film gelora nasional (the 'passion of the nation' films) (Prakosa 1997:184). The method of distributing these messages was through the practice of film layar tancep (Biran 2009). This method entailed projecting these national glorification films in open-air settings for the public to view and moving the film and projector throughout the nation from village to village (Prakosa 1997:184). The concomitant ideology is apparent in the governmental body responsible for this practice, the Departemen Penerangan. While this is routinely translated as the Department of Information, the root of the word penerangan is 'light' (terang); the Department of Information transmitted light both through film as well as through 'enlightening' rationalities.

With the New Order, the content of film pendek shifted from film gelora nasional, films which sought to 'set ablaze the passion of the nation for increasing their love of "this land and water [Indonesia]", to film gelora pembangunan ('passion for development' films), films depicting a passion for construction or 'development' (Prakosa, Atmowiloto and Rendra 2006:46). But the practice of disseminating governmental ideology through the audiovisual medium to the population connected both regimes. Both regimes built their cinema infrastructure with the aim of interpellating audiences into citizen-subjects.

Despite this continuity, a qualitative shift took place between the open-air layar tancep screenings of film gelora nasional and the television screenings of film gelora pembangunan that separates two modes of hegemony and interpellation. For the personal television puts the mouthpiece and images of the state into the homes of Indonesians in the late 1970s. This serialized dissemination of government ideology by TVRI into the private home was the televisual field that Gotot, geographically and conceptually, redetermined through the practice of film pinggiran, for it ejected the social reception of film outside of the private home and the television. Like the practice of layar tancep screenings, Gotot and his collaborators brought and screened films from village to village. But rather than nostalgically mourning the loss of film gelora nasional, film pinggiran disrupted the hegemonic conditions of interpellation that TVRI actively engendered.

Gotot's A film about family planning (1979) dramatically illuminates how he both maintained the statist form of film pendek while also bringing about its determinate negation. One of TVR I's flagship broadcasts were short film advertisements for the family planning programme, Keluarga Berencana (Кв), which instructed Indonesian citizens that 'two children are enough' (Kitley 2000). кв was important to the Soeharto government as it was an early programme 
which received the backing of foreign development funding (Warwick 1986). The programme evinced how deeply intertwined the military was in the regulation of life in the New Order of Indonesia, for the family planning programme integrated their promotional activities with the military at local levels of government (Warwick 1986:458). The government used film pendek to spread the message of кв through television, as well as through open-air layar tancep public screenings (Kitley 2000).

Like the gelora nasional films of the 196os, the distribution of кв film pendek was a territorial practice of the government, spreading these films throughout the islands of Indonesia as a symbol of Indonesia (Kusumaryati 2013). In addition, the audio-visual message was, as in prior regimes, an oracle that instructed and established nationalist norms. Despite this continuity, a formal discontinuity had also taken place. For the normative collectivity addressed by the film had shrunk from the unfinished, surging nation in the film gelora nasional to the planned, enclosed nuclear family of кв. In one governmental кв film pen$d e k$, an ideal family is depicted: a father returns from work, holding a briefcase, and reaches down to hug his daughter while his son leaps in joy. Furthest in the background, the mother waits in front of the family house for her husband. The intertitle text reads 'A small family with great enthusiasm and expectations'. ${ }^{6}$

Gotot produced A film about family planning (see Figure 3) in 1979, which maintained the same form of a film pendek 'about family planning'. But in Gotot's version, a painted penis flutters on the moving image, searching for a painted heart. After they meet, another heart grows within the heart, which eventually gives birth to the smaller heart. The process repeats several times until the hearts join in a circle to prevent the penises from entering again. The penises, accompanied by the rapid music of 'Flight of the bumblebee', appear in a frenzy, unable to conjoin with the hearts. In the end, the penises wrap around each other, moving up and down together, producing more hearts. After this climax, large black question marks blink in the background as this 'film about family planning' finishes.

While maintaining the same film pendek form as the governmental cinematic campaign, this film parodizes the glorification of family planning. But even if it obviously lampoons the state narrative of family planning, the film's narrative content itself remains ambiguous, as dramatized by the final flickering question marks. For it is the normalization and standardization of life and eros by the New Order, as actualized by the dissemination of $\mathrm{KB}$, that is entirely refuted by the film. Though the government's кв films were nominally

6 'Jadul TVRI-GenerasiKB'. http://www.youtube.com/watch?v=XMvVHayQTjg (accessed 1-72020). 


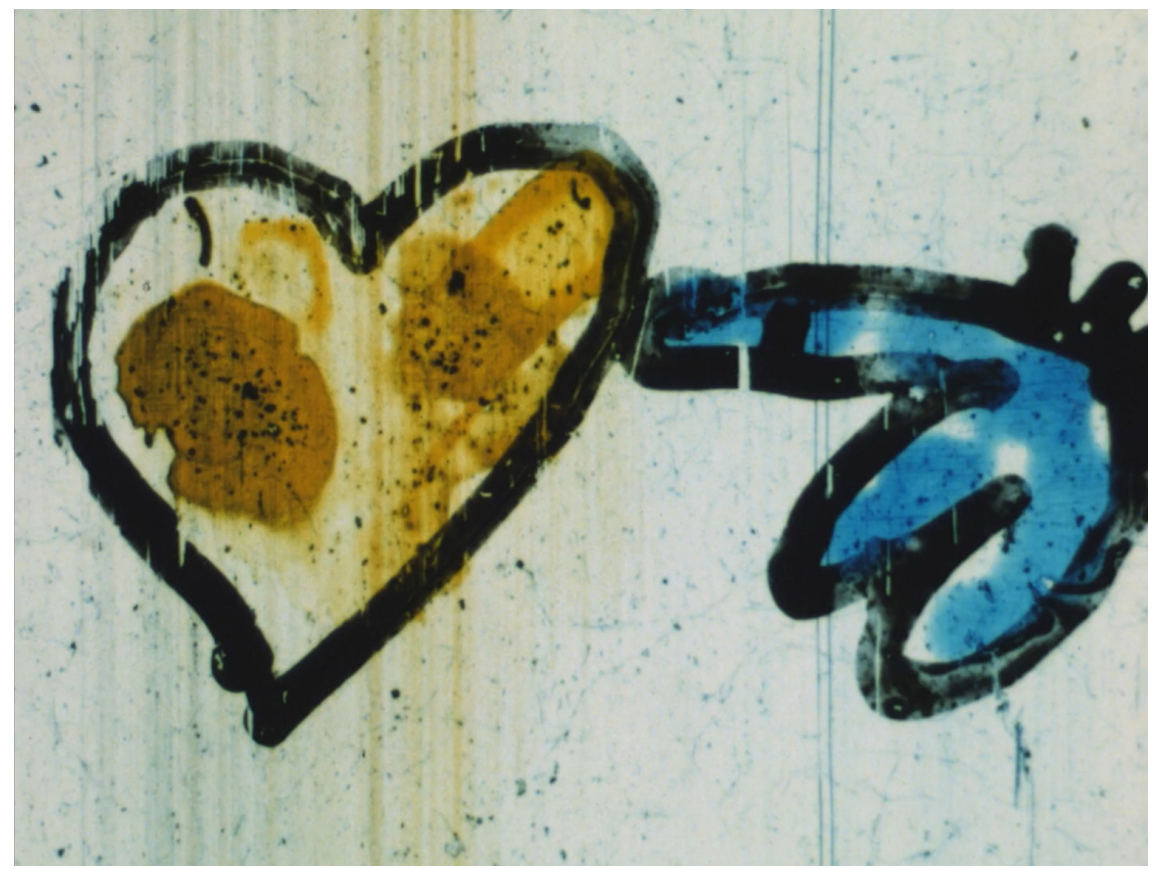

FIGURE 3 A film about family planning, Gotot Prakosa, 1979

about family planning, there was no reference to sex. In Gotot's film, on the other hand, the depiction of penises and splayed female human legs at birth themselves contradict the foreclosure of sex in the state cinematic depiction of family planning. Likewise, the conclusion of coiled penises generating question marks is neither a purely ethnographic nor eschatological statement regarding the potential for homoerotics as the result of family planning. Rather, this ending advances into the film's screening an erotic and unpredictable notion of life and sex that the New Order government's image of family planning actively attempted to eradicate. Sex is deposited in the threshold separating the end of the film from its reception, which is precisely what the governmental кв films excised.

But to shield this art practice from the attention of the New Order, Gotot situated his practice within the discourse of the state tradition of film pendek. In a submission to the Dewan Kesenian Jakarta (Committee of Jakarta Arts), seeking financial support to travel and attend film festivals, Gotot wrote:

In the 196os, we watched 'the passion of the nation' film pendek (short films) that were broadcast in the cinema before a long film (narrative film). At that time film pendek were used to ignite the passion of the 
people and intensify their love for 'tana air'. But it is a pity that this activity disappeared before getting the opportunity to evolve and improve.

PRAKOSA, ATMOWILOTO and RENDRA 2006:46

The passage places his film pendek practice into the lineage of the gelora nasional films, thus portraying his own film project as a continuation of this nationalist project. But the statement exhibits how Gotot used nationalist and developmentalist cultural tropes as alibis for his film practice. He wrote: 'We need a spirit that produces solidarity for struggling against the condition of film from our individual lives that are still consumptive', thus appealing to the New Order's rejection of a consumptive lifestyle, but also leaving the actual subversive content of his film practice unexpressed (Prakosa, Atmowiloto and Rendra 2006:59). His film practice thus drew on hegemonic forms of film production and circulation only to decentre their putative content from within.

\section{Marginal Films and Films at the Margins}

Behind the presentation of film pendek as an art form to further the nation's development, Gotot and his collaborators reversed and inverted the paths of film production and circulation in Indonesia, taking flight from centralized infrastructures and their concomitant forms. This excentric film practice was characterized by a double displacement. It displaced the physical site of the reception of film out of the cinema and TVRI and into informal and often unsanctioned localities, while simultaneously dislocating the aesthetic orientation of film production away from 'central' forms. Gotot and other film-makers called this practice sinema ngamen (busking cinema), film pinggiran (marginal film), and sinema jemuran (clothesline cinema). The names all indicate an aim to create encounters with film that generate a discrepancy with the hegemonic forms of address of TVRI and its habituated sites of dispensation in the commercial cinema and home television. These productive and circulatory practices generated situations in which cinema cultivated speculative, rather than quiescent or obedient, forms of thinking in the audience.

In describing these practices, Gotot opens a chapter entitled 'Seeing honesty through film pendek' by saying:

Well, what is meant by 'film pendek' or alternative film here are films whose moment of projection are determinately outside of the stipulations and conventions of narrative films in the cinema.

PRAKOSA 1997:25 
This film practice was thus primarily oriented to produce encounters with cinema that were detached from normative and institutional conditions. These encounters thereby facilitated a strike on reproducing the hegemonic narrative forms and circulatory infrastructures of the moving-image mass media in the New Order. Gotot described the logic and environment of these screenings in the following two ways:

There was an idea for showing the film works of university students in the villages, going door to door if they had to, busking in the street, so that the name busking cinema (Sinema Ngamen) arose. Screens for showing films were also very limited, so that even bedsheets that were being dried in the sun could be used for a screen, so that the term clothesline cinema (sinema jemuran) arose and it meant that even drying bedsheets could be used to show films.

PRAKOSA, ATMOWILOTO and RENDRA 2006:3

Busking Cinema is called busking because its mission is really to appreciate the style of busking. Bringing an $8 \mathrm{~mm}$ or $16 \mathrm{~mm}$ projector with some film titles and some film works made by us and our friends, to be watched in the $\mathrm{RT}$ or $\mathrm{RW},{ }^{7}$ that is busking and it carries out the mission to socialize film pendek or alternative film. The showings don't need anything else. If there is a meeting room, we can show it there. In a school, there too. In the yard, there too. This approach is more humane. People are thereby not too distant from the media, which usually are exclusive. Busking cinema and clothesline cinema can be considered to be trying to make film into a human thing.

PRAKOSA 1997:117

This project to 'humanize' film at once negatively acknowledged the exclusivity of television and the cinema, while also positively producing another, more 'humane' place for films in non-specialized spaces and social formations.

Stripped of its vocation as entertainment and mouthpiece of the sovereign, this film project turned the projection of film into a place for pedagogical encounters. Describing the conditions of these screening situations, Gotot wrote:

Film, to put it simply, is really only an arrangement of images that exist on celluloid. They are then rotated by the technology of the projector.

7 Rukun Tetangga (RT, Neighbour Association), and Rukun Warga (RW, Citizen Association), are the two smallest geographical levels of Indonesian government administration. 
This actually offers a breath of democracy; various meanings can be interpreted. Film offers sundry messages; it can be used for a variety of purposes. Because of this, film becomes very interesting when examined from several sides.

PRAKOSA 1997:22

As sinema ngamen, film pinggiran, and sinema jemuran, film transforms pictures on celluloid into moving images in time that effectuate a 'breath of democracy'. This 'breath of democracy' emerged because this film practice engendered a displacement in the conditions of hegemony. In that gap, these viewers encountered a somatic subjection to democracy. Democracy here does not mean that the films prescriptively conveyed the normative ideological content of a democratic polity. Instead, democracy here expressed how viewers themselves generated the understanding, ideas, and meaning of the images. These moving images, without a pre-determined and resolved meaning as in film gelora pembangunan and TVRI more broadly, elicited an answering back from the viewers. Film pinggiran thus made film an experimental condition for democratic subjection in the New Order.

The increasing marginality of film brought about by Gotot emerged in combination with several constitutive elements that originated from outside Indonesia. D.A. Peransi, Gotot's foundational film teacher at IKJ, had made films in Indonesia during the 196os but was dramatically impacted by his time studying film in the Netherlands from 1970 to 1972 . Upon returning to Jakarta, he told Gotot and others about existing revolutionary film-making, especially the New Wave in France and New German Cinema in Germany (Prakosa, Atmowiloto and Rendra 2006:1). That this European cinema revolution was created by student film-makers kindled the idea for these young Indonesian student filmmakers that film could be made with aims other than purely commercial or governmental ones (Prakosa 1997:2).

The $8 \mathrm{~mm}$ and $16 \mathrm{~mm}$ cameras used by this film pendek generation also came from abroad (Prakosa 1997:5). Gotot himself received his camera as a gift from an uncle who went abroad. For Gotot, the camera was a tool that felt like 'a "petel", the weapon of Petruk, the servant who wherever he went, brought this treasure at his waist. I also was like this' (Prakosa 1997:2). Petruk is a Javanese wayang character, who is often understood as presenting himself as a foreigner in Java (Riantiarno 1995). Gotot's statement articulated how he saw himself and 
his weapon as not completely autochthonously from Java but instead bearing some foreign element. But it also indicated that his camera was not a sybaritic toy but, instead, a weapon.

Yet Gotot did not make films with the documentary or fictional narrative structures to which D.A. Peransi remained faithful. Although he does not directly refute the language of the New Wave and D.A. Peransi, the motivation for making short, experimental films was clearly stated by Gotot: "The majority of films [narrative and documentary] are used as "storytelling tools" and not expression' (Prakosa 1997:30). This contrast between film as a 'tool for storytelling' and 'expression' is analogous to the distinction Gotot draws between the centre and the pinggiran, where the centre comprises arts which tell stories but do not challenge the notions or normativity of the centre. He, instead, created aphoristic expressions which solicit dimensions of human thought and feeling that are not made available with 'storytelling tools'.

Furthermore, as an IKJ student, Gotot witnessed myriad foreign documentary film-makers coming to Indonesia to shoot documentaries (Prakosa, Atmowiloto and Rendra 2006:8). These experiences with foreign documentarians facilitated an understanding from a young age about the position of the camera and its gaze. Watching these foreign film-makers in Indonesia insert their camera into every aspect of life, 'tanpa sungkan dan was-was' (without hesitation or doubts) and 'tidak merasa menyalahi sopan santun atau etika dan tata krama dari kebudayaan lokal' (not feeling like they were violating politeness or the etiquette and manners of local culture) cultivated the understanding that the camera can transgress cultural forms and limits (Prakosa, Atmowiloto and Rendra 2006:8). The lesson learned was not only that film-makers can insult local customs; Gotot also recognized that as a 'modern' Indonesian, he was not the object of the foreign gaze. He thus recognized that his position as a filmmaker was on the cusp of the city and the 'exotic' periphery which entirely eluded foreign documentarians.

During his years as a student at IKJ, Gotot travelled with friends from the anthropology department of the University of Indonesia to meet and film other Indonesian cultural forms that were not 'modern' (Prakosa 1997:3). Although some of these trips took them long distances to other islands, Gotot also travelled to the Badui people near Jakarta in West Java, who have resisted the uptake and incorporation of machinery and electricity. Recalling this experience 30 years later, he wrote:

In Outer Badui, there was a place where the residents had left, because at that time there was a programme by the New Order government, named 'resettlement', which had prepared a new village for the people of Outer 
Badui, who dress entirely in black and wear black cloths on their heads, near Lui Damar, to help them to become 'modern'. We were invited by a villager from Outer Badui, already a good friend of Don [a friend of Gotot] to see a destroyed village, where the houses had been made from cheap wood, which had been destroyed by termites and broken down by rain and heat, but because they were not occupied, they were ready for destruction.

PRAKOSA, ATMOWILOTO and RENDRA 2006:7

Through this travel experience, Gotot recognized how the New Order project of 'development' interlaced the livelihoods of indigenous people with environmental destruction. He furthermore grasped a fundamental semantic of margin, for the people living at the spatial margins of the Indonesian nation state were also in the process of being marginalized.

In constituting the category of modernism, without positive or prescriptive aesthetics, in which artists try to create the new, Frederic Jameson situates its arrival and departure as due in part to the experience of the urban intellectual, who senses, through travel, a vast gap between the city and the not-city. Jameson argues that this feeling led the European modernists to raise the qualitative question of time - how 'long' separates the city from the countryside? not as an intentional aesthetic ideology, but as a consequence of the spatial fragmentation engendered by capitalist development. It was the particular position of late nineteenth- and early twentieth-century European urban intellectuals, according to Jameson, to travel between these two situations and experience the shock of cultural separation. Modernism is not thereby a quest for the new, but a reaction against the representational codes of realism, which were deemed incapable of conveying the feeling of shock of arriving in a not-city from Paris or Vienna (Jameson 2002:141-215).

While the same structure and experiential shock, brought about by travelling between the city and its non-identical form, worked on Gotot in the late 1970s, its significance was not identical to the travels of Proust or Mann. For it was the particular distinction of the 'Third World' urban film-makerintellectual to recognize that while Jakarta is not Badui, Indonesia is still an 'exotic' locality for Europeans. This, combined with the recognition that the Indonesian government was actively destroying the civilization of the 'premodern' in the name of 'development' and 'resettlement', delivered another kind of answer to the question of the qualitative temporal separation that is sensed between the city and the not-city. For Gotot, the qualitative temporal gap did not exist only within the national situation, but also between national situations. 
This was underscored by Gotot's first overseas trip to the Philippines in 1981. The Goethe Institute in Jakarta facilitated Gotot's journey to participate in an animation workshop. This plan was upended immediately after arriving in Manila, where students were protesting against President Marcos (Prakosa, Atmowiloto and Rendra 2006:21). As an Indonesian coming from the conditions of the New Order, the experience of witnessing Filipino students fighting against the injustice of their president produced recognition of a spatially noncontiguous similarity, not difference, between the authoritarian conditions of Indonesia and the neighbouring Philippines. Rather than differentiating the capital from the province, this encounter offered a sense that the authoritarian conditions of Indonesia were not an isolated phenomenon. This was not the radical otherizing of the city and the countryside but, instead, the identification of an illiberalism that traversed Indonesia and beyond.

The contours of this cognitive mapping intensified a few years later, when Gotot, again invited by the Goethe Institute, travelled to Germany to show his films at the Oberhausen Film Festival. Although this 1984 trip to Germany was predicated on Gotot showing three of his films (Meta ekologi, A film about family planning, and Dialogue) at Oberhausen, the most dramatic experiences of the trip were not showing his works but instead watching television and art house cinema in Frankfurt. For Gotot, these screenings re-determined the identity of the public sphere in Indonesia at that time. He wrote of the experience:

At that time I saw that Art House cinema was already quite established in Frankfurt, so I began to imagine and just think of whether in Indonesia there was a building like this. But in reality it is totally different. In Indonesia there is Minister Harmoko who is happy to appear in Klompencapir on TVRI.

PRAKOSA, ATMOWILOTO and RENDRA 2006:18

It is the apprehension of this separation, between the public sphere controlled by Harmoko and the Frankfurt Art House cinema, which shocked Gotot more than any of the 'extreme' aesthetics of the films screened at Albertz Hall in Oberhausen (Prakosa, Atmowiloto and Rendra 2006:18). Gotot's recognition of the control of the mass media by Harmoko and TVRI sharpened and intensified after seeing the masses of ordinary urban citizens in the Frankfurt cinemas. 
In order to understand how Gotot intervened in, and disrupted, the circulation of ideology in the New Order, this article turns to the aesthetic realization of the pinggiran in the films Jalur (1977), Meta ekologi (1979), and A ... Absolute ... $Z$... Zen ...? (1983). All of these films bring forth common audio and visual topoi, but in a mode that contradicted their typical, hegemonic formations as transmitted by the New Order mass media. In particular, the films dramatically re-present the problem of 'development', which Ariel Heryanto, amongst others, identified as a keyword of the New Order ideology (Heryanto and Lutz 1988). The films do not therefore construct a novel notion of 'development' so much as they negatively identify the hegemonic notion of 'development' promulgated by the New Order. In doing so, the films situate a visible dislocation in the notion and appearance of development and technology.

Jalur (Lane, as in a lane of a road) (1977), shot with a $16 \mathrm{~mm}$ Bolex camera, was one of Gotot's first camera films (Prakosa 2010:255). The visual images were produced by fixing the camera onto the top of a bus and recording the trip driving the road from Jakarta to Bandung (see Figure 4). The film's image looks directly forwards, at the backs of sundry buses, motorcycles and trucks and occasionally, the open road. The sides of the road, filled with small shops in the outskirts of Jakarta, give way to sawah (rice fields) as the journey leaves the metropolitan area and climbs into the mountains. But this 180-kilometre bus trip is condensed into just 12 minutes of film. The film is thus the vision of a bus trip at 'hyperspeed'; speed is thus the form and content of the film.

When David Hanan, an Australian film-scholar and a long-time interlocutor of Gotot, facilitated the publication of a collection of Gotot's films through an Australian academic film publisher in 1999, Gotot offered in the liner notes of the vHS a short and oblique statement that 'this film is the expression of the trip, as though it were a meditation, a trip in which you ignore everything around you'. 8 But writing in Indonesian in 2010, Gotot offered another narrative that, while not in contradiction with his first statement, dramatically sharpens its articulation:

The film work by Gotot Prakosa entitled Jalur (The lane) (1977, 12 minutes), 'is about' recording a journey from Jakarta to Bandung atop a vehicle. The journey is recorded and focuses on mood, or atmosphere [...]

8 'Short films, videos and animation works by Gotot Prakosa'. http://artsonline.monash.edu.au/ mai/work-by-gotot-prakosa (accessed 1-5-13). 


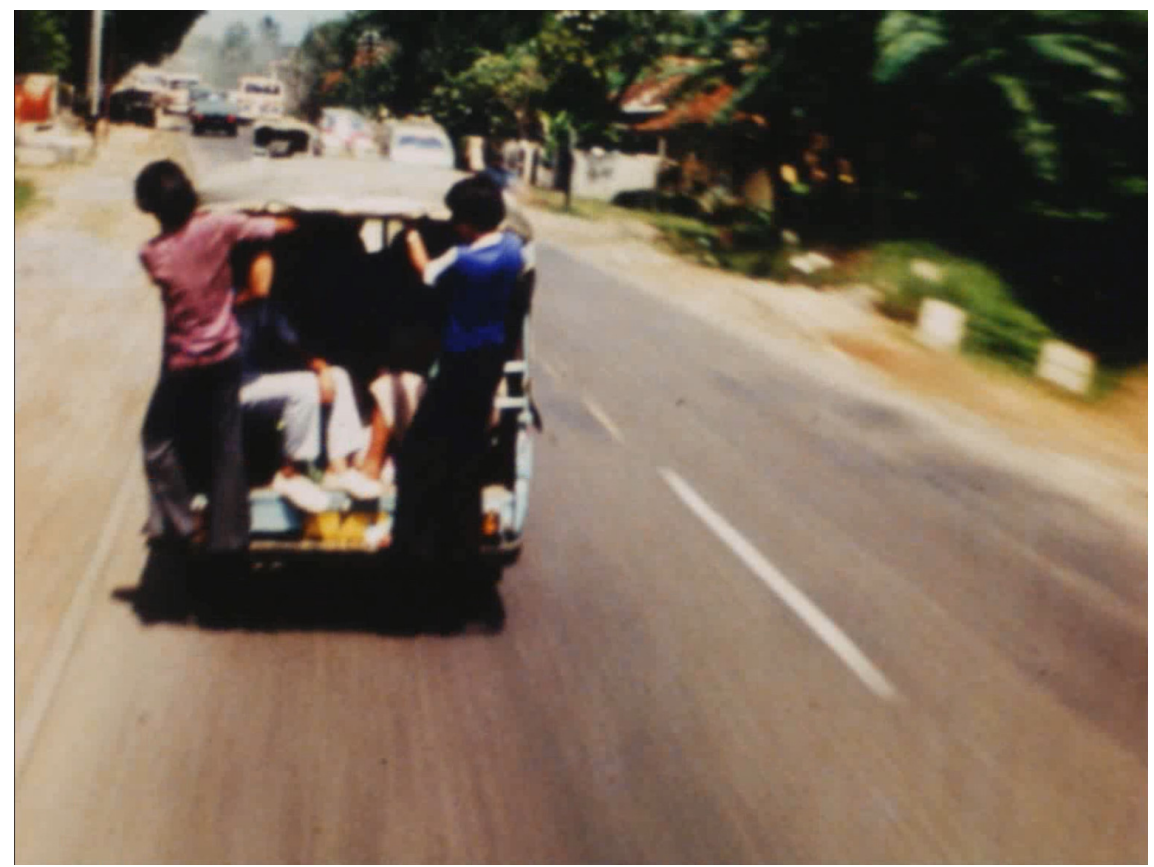

FIGURE 4 Jalur, Gotot Prakosa, 1977

Actually, the idea of documenting this journey came from the aim to build a toll road from Jakarta to Bandung. It was predicted that in the future cars would not use this road through Parung. In the future, Jakarta and Bandung would feel closer because the new road would cut through on a direct path. On the basis of this, there was the idea to document the road through Parung which later would be abandoned by travellers who would instead choose the toll road. The concept of the film is that the real duration of the journey, which takes about 6 hours, will be compressed to become 15 minutes more or less, turning it into 'film time'.

PRAKOSA 2O10:255

While the film is animated by the 'development' aim of the New Order government, this is narrativized in an oblique, abstract manner, for the film has no spoken voice track. It includes the specific narrative of the modernization project of building new roads at the same time that it presents a general tableau vivant for the recognition of other narratives of 'development'. This is accomplished by transforming an everyday vision of the road into an aesthetic idealization of terrifying speed. This reconstitution of the common does not concretize another individuated narrative as much as it furnishes a visual 
field for negating the gaze that depicts the 'development' of the New Order as uncomplicated progress.

The sound of the film, like the visual register, draws on common soundimages, while redefining them with an identity that contradicts their natural habitats. On the one hand, there are the noises a traveller regularly hears on the road, such as the combustion explosions that provide energy for transportation vehicles, the horns of trucks and automobiles honking, and bus brakes screeching. This is interpolated with slow music from the very region that the camera enters into on the road. The Sundanese kecapi suling music, performed using antiquated instruments, is a contrapuntal tonic to this terrifying speed. Thus, the film is not a classical documentary of a road but, instead, an expression of a more general co-presence and contradiction between the mode of production of the society that produced the speed of kecapi suling and the one that produces not only the speed of the automobile and camera but also the film technology to accelerate speed and compress time.

The film echoes a canonized joke by Abdurrahman Wahid (Gus Dur) about why bus drivers are more noble (mulia) than presidents or preachers. In the joke, when bus drivers arrive at heaven, the angels let them into a large room made of gold, but when the former presidents and preachers arrive, the angels give them only a small room made of wood. Gus Dur explains the paradox: when the former presidents and preachers speak, people become tired and fall asleep, but when the bus drivers drive quickly and erratically, people pray (Jabrixs 2010). The film, through its hyperspeed, makes the viewer feel a bit sick, bringing about a kind of meditation, if not prayer.

But the film does not provide comfort for the viewer; it suggests instead that these vehicles are themselves an inescapable mood and speed of modernization. As the film shuttles the audience between the geist that is frozen in the timbre and tempo of this Sundanese music and the one ossified in the automobile, the result is a vision which contradicts the panegyrics of film gelora pembangunan and TVRI, which instruct that the road is the manifestation of a developing society. Instead, the film situates speed itself as inviting exploration of the true meanings and experiences of technology and 'development'.

The Sound of Class Struggle: Meta ekologi (1979)

The film Meta ekologi (Meta ecology) (1979) is the cinematization of a dance performance choreographed by Sardono W. Kusumo. Like most of Gotot's films from this period, it does not contain any spoken language. Instead, as in Jalur, depictions of common social forms are both drawn upon and contradicted 
through the montage of sound and image. The result is not a simple redetermination of common topoi so much as a determinate negation of the gaze that distributes a visibility of ecological relations and agricultural labour as simply harmonious.

In an exchange with the Cantrills in 199o, Gotot described the film as follows:

That [film] was made in 1979, and based on a performance by Sardono W. Kusumo and his group. We see them in a mud pool in a slum district of Jakarta, with the local people watching the performers who become entirely covered with mud. It's a response to an attempt to enter into dialogue with the ecology of earth and water -

humanity expressing its feelings through the body by trying to become one with the universe. It has references to farming peasants, working on the land and covered with mud. It's a process of poeticization.

PRAKOSA 1990:26

The film begins with the dancers standing outside of a field of mud. They slowly begin to enter, fall down, and become completely submerged in the mud. As Meta ekologi was shot in black-and-white film, the bodies of the dancers assume hues of the colour of mud (see Figure 5). The only white colour in the film is the brilliant white clothing of a man who smokes a pipe while the others prepare the sawah before the dance begins. Dutch colonial officers wore white suits in Java and this form of dress indelibly differentiates his body from those of the muddied dancers. Although the man in the white suit remains pristine as the others struggle in the mud, by the end of the film, he too wades into the mud, swinging his arms violently, only to be swallowed up by it. While this costume indeed visually indexes the colonial relationship, the sartorial signification is not exclusively Dutch. Rather, this marking of the bodies forms a generalized narrative of land and class division; while the masses labour in the mud, the few wear clean suits outside of the mud. However, even the comprador himself is eventually consumed by this meta-ecological metabolism and inhumation.

The dancers' bodies fall, in the shape that a tree falls, their arms fixed at their sides the entire time. They lie like corpses in the mud before they begin to move again. Their bodies, alone, then together, struggle, in chains, pushing then pulling, and rolling over each other. There is no cessation, no rise or fall to the speed of the movement. No strategy of movement changes the conditions; when one man manages to exit the sawah, the others throw mud at him and he throws mud back at them.

Although the film Meta ekologi is without a linguistic metanarrative, land and environment are identified in the film as signal localizations of struggle 


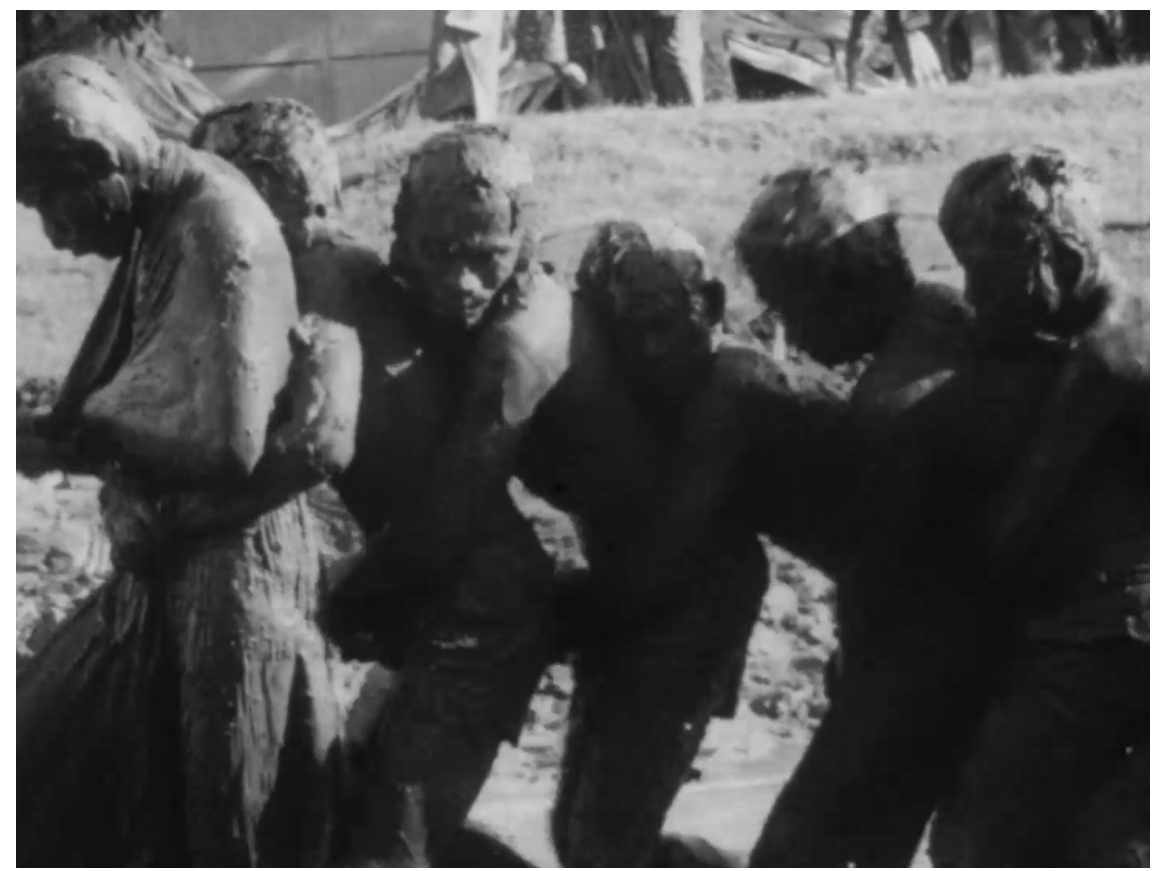

FIGURE 5 Meta ekologi, Gotot Prakosa, 1979

writ large. In a coeval statement in an IT B student newspaper article, commemorating the one-year anniversary of the government programme Normalisasi Kehidupan Kampus (Normalization of Life on Campus), Heri Achmadi, then a student activist, wrote:

Members of the Soeharto family hold the monopoly for cloves (for cigarettes) which results in an income of billions of rupiah, forestry concessions and rights to use land for plantations [...] In this way, they give life to the Berkeley technocrats (Berkeley mafia) entrenched in Suropati, ${ }^{9}$ who have prepared a draft plan for the economy that is very conservative and against the people of society. The draft for the development of the economy has a liberal capitalist orientation that uses the free market as a key mechanism for the economy of Indonesia, clearly only benefitting those who have strong capital and high management, which are the possessors of foreign capital and the Chinese finance barons.

ACHMADI 1979

9 Suropati refers to Taman Suropati, the location of the Badan Perencanaan Pembangunan Nasional (National Development Planning Body). 
At the same time, the euphemistically named Revolusi Hijau (the Green Revolution) brought the cultivation of standardized rice strains, a transformation enforced by the Indonesian military (Welker 2012:391-2). Land and environment, therefore, were not merely ancillary aspects of the student-led opposition to the regime of Soeharto in 1979. Instead, they comprised its foundation.

In the mud, the dancers climb on each other's backs up a mud-slicked tree trunk. This is a common, recognizable national symbol: the ritual of manjat pinang (climbing a palm tree), practised every 17 August to celebrate Indonesia's Independence Day. Men stand on each other's shoulders, 'working together', in order to reach the top, where a chandelier of prizes is placed. But in Meta eko$\log i$, as the camera slowly pans up, following the men climbing on each other, the shot concludes by showing that there are no prizes at the top of this tree trunk: it is simply empty.

While there is no univocal meaning imputed by this filmed dance performance, it does negate recourse to habituated visual and sonic identities and their concomitant ideology. A fertile sawah has often served as a synecdochical visual representation of a healthy and prosperous Indonesian society (Protschky 2011). But in the sawah of Meta ekologi men take the form of a water buffalo and the top of the manjat pinang tree is without any rewards. As in Jalur, common cultural topoi are not reinvested with a new master narrative; rather, their depiction intimates realms excluded by the normative hegemonic gaze.

The soundtrack of the film is formed of the sounds of the crickets and frogs heard at night in the sawah or desa (countryside). The sounds from these distant places frame and accentuate the contrast with this constructed dance space simulating a wet rice field in a 'slum district of Jakarta'. For the film at once draws on the ideological distinction of the 'original' sawah and the city, while also dissipating its typical binary solution. The separation of the desa from the kota in geographical and ideological ways is a dominant motif in Indonesian art and films. D.A. Peransi, in surveying the 'concept of social life in Indonesian film', cites as its first characteristic the separation of the countryside from the city as a narrative pattern in Indonesian cinema (Peransi 1997:144). But it is not that they are merely separate; conventional films work to consecrate this difference. In mass culture films, the city is typically the place of hedonism and sin, while the countryside is the source of 'well-mannered' women and supernatural power (Peransi 1997:144).

Although Meta ekologi draws upon the reified social difference of desa and kota, the film does not reinforce its typical normative pattern. The reconstitution of the sound of an 'original' desa at the site of this urban, fabricated sawah 
generates a cognitive mapping where there can be no facile or final determinate separation of the city from the countryside. The ecological and class struggle of mankind will not observe these geographical boundaries.

The film thus does not provide a single definitive reconstituted narrative of ecology. Rather, by contradicting the hegemonic meanings of 17 Agustus, manjat pinang, and sawah, the film generates a mood intimating that mankind and the earth are engaged in a struggle and that no solution can be seen or heard. The film instead avers that the sawah cannot be a site to mark visible tranquillity, prosperity, and social health. Both Jalur and Meta ekologi decentre without recentring common topoi. They thereby render what hegemonic depictions excise, which is the mood of disquietude itself.

The Estrangement of an Eidos: $A$... Absolute ... Z ... Zen ...? (1983)

The aesthetic project of the pinggiran is further realized by Gotot in his $A$... Absolute ... Z ... Zen ...? (1983). Whereas the expressions of Jalur and Meta ekologi emerged primarily from the contradiction within the synchronic montage of the sound to the visual image, $A$... Absolute ... Z ... Zen ...? , as the title suggests, situates its contradiction in diachronic montage. The film generates both uncertainty regarding naturalized narratives of linear progress and development, while also warding off any resolution at the very moment that the film ends. By abruptly ending without a univocal conclusion, the film thus takes the problems generated by the film out of the film itself, and passes their resolution on to the audience. Imbricating the audience into the completion of the film itself, it manifests the telltale aesthetic strategy of film pinggiran of disarming habits of docile observation.

The 14-minute $A$... Absolute ... Z ... Zen ...? is a narrative of the nineteenth and twentieth century in Japan, drawn from the perspective of an Indonesian animator. The film opens with the sounds and visions of classical, pre-modern Japan: men and women in robes, Buddhist temples in sylvan valleys, paintings of cresting waves, a society of pious Buddhists, flowering trees, all set in a slow montage to spare, slow string music.

A sitting Buddha appears from the horizon, becoming larger and closer as the sound of gong music tolls; the image serves as an intertitle marking a boundary with the next sequence. In the next sequence, the lifeforms of 'pre-modern' Japan are confronted by men wearing tall black boots and featuring red circles on their cheeks and hats. Though the animation does not give them human voices, their mouths are shouting and their brows are furrowed. Without guns or corporeal violence, the old, pre-modern forms, which 


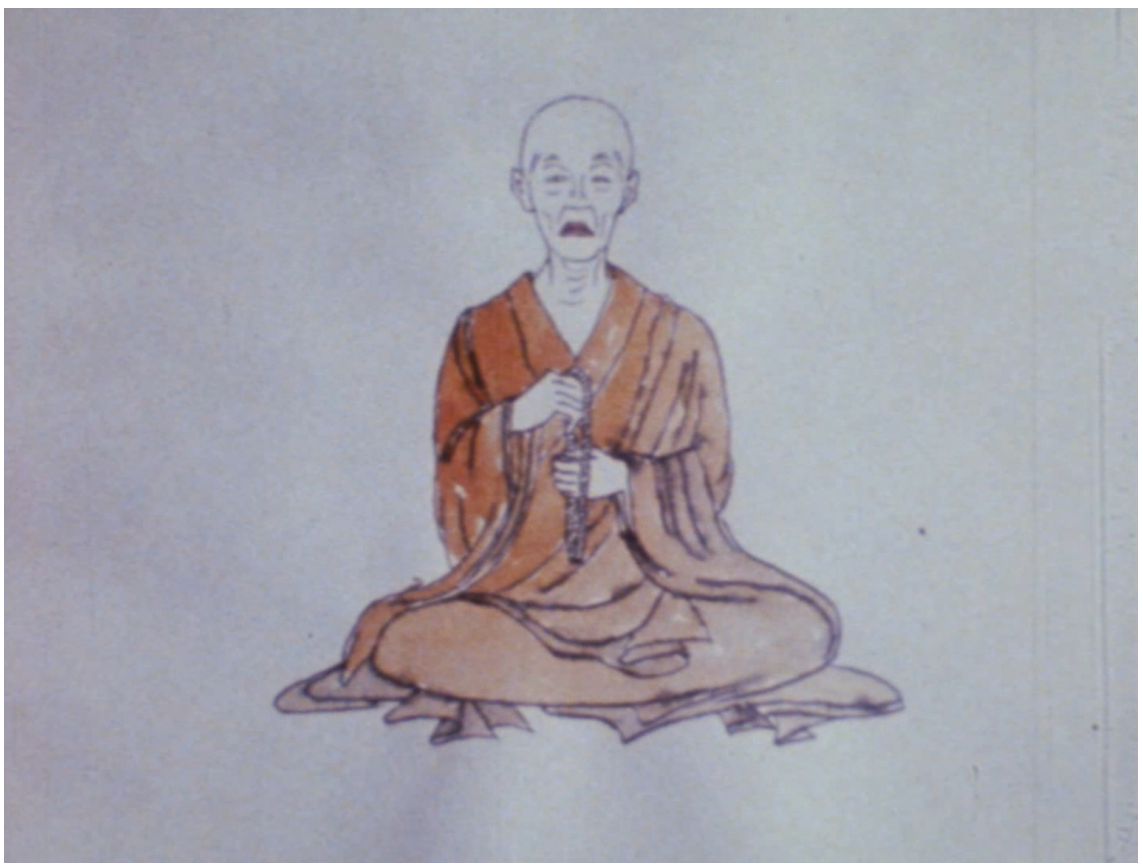

FIgUre $6 \quad$ A... Absolute ... Z ... Zen ...?, Gotot Prakosa, 1983

populated the first section of the film, appear, each alone in a frame, flickering momentarily, before they are extinguished.

After another intertitle of a Buddha arriving from the horizon, another composite vision and sound of Japanese society fills the screen. A sallow, frowning man, featuring fading red circles on his cheeks and wearing a business suit and tie, occupies the entire frame, rapidly swinging his arms and legs. Though he appears as a person who is running, he never moves. His body transforms into a beautiful large white bird, which then transforms back into his immobile jogging body. The accompanying syncopated and dissonant music, produced by Tony Prabowo, generates an unsteady rhythm that is suggestive of a pallid man who is stuck yet still appears to be moving.

After another Buddha intertitle, the next sequence depicts the birth of modern military machines. Birds, flying in the sky, transform into airplanes with missiles, guns, and bombs. Military men featuring red circles on their cheeks search the wartime map of the world and circle Indonesia. But this story does not conclude with this well-known moment of the Japanese invasion and occupation of pre-Indonesia. The animation then turns from this historical sequence to a photographic montage of Japanese Buddhist architecture. The photographs of temples that compose this sequence give way to a montage of 
photographs of the architecture of modern industrial Japanese society: highways, power plants, factories, smoke stacks, apartment buildings. These are the very images of national development glorified on TVRI.

In the final segment, the production of missiles and war airplanes proliferates until giving way to the superabundant production of modern industrial commodities which were imported en masse from Japan to Indonesia in the 1980s. First the truck, car, and motorcycle appear, followed by a flood of audiovisual communication devices: the photographic camera, telephone, television, and finally the film camera, the very audio-visual technology used in the production of the film $A$... Absolute ... Z ... Zen ...? itself. This frenetic montage of devices is relieved by a final sleeping Buddha, depicted with a long chain of 'zzz' in his thought cloud, leaving the question of technology present though unresolved by the film.

As the film has already habituated a diachronic and historical narrative, this final sequence evinces a historical shift from the social and aesthetic vision of Buddhist architecture to the vision of modern industrial architecture. Whereas the aspect ratios of the photographs of the Buddhist temples harmoniously balance height and width, the photographs of modern architecture are not artistic compositions as much as functional snap-shots which could appear in technical manuals. The sequence thus illustrates a shift between the architectural principles of a society expressing formal harmony to one ruled by massive technical function.

This shift in the principle of architecture and technology intervenes inand interrupts - the historical narrative of the film. In the conversations that accompanied the screenings of footage shot in indigenous communities throughout Indonesia, architecture was a central issue in discussing the question of development. Gotot writes:

Essentially, film provides authentic data to answer questions regarding the state of development of culture at that time. This could be an ecological situation, or a cultural situation itself, such as dance and the existence of traditional houses, meaning that architecture itself became the main subject of discussion after film screenings.

PRAKOSA, ATMOWILOTO and RENDRA 2006:12

At a time when TVRI celebrated the inaugurations of factories and bridges, filming the co-presence of 'traditional' architecture and its destruction in the name of development provided the 'authentic data' that not all societies in Indonesia had valorized the aesthetic principle of the factory and the bridge. Architecture made visible the transformation called development. By depict- 
ing this sequence in Japan, $A$... Absolute ... $Z$... Zen ...? avoided any danger of being identified as subversive by the New Order. But the transformation also showed the path of change in Indonesia, as Gotot had witnessed with the Badui.

The film is not the tragic story of the violent twentieth-century Japanese invasion of Indonesia; instead, the twentieth-century narrative is its mechanization. In Japan, as in Indonesia, the film depicts a shift from 'traditional' architecture to the rise of industrial architecture. But unlike TVRI, the images in the film do not testify to a progressive development. They depict a functionalization in the social and aesthetic principle of what is seen. By concluding the film with the emergence of the personal film camera, it attests to the intervening role that audio-visual technology has in orienting visibility and the social as such. But rather than arguing for an impossible and romantic return to the 'pre-modern', the film opens an examination of the fundamental purpose of architecture and technology.

\section{Conclusion: The Potentiality of Uncertainty}

The endings of all of the films discussed in this article dissolve the finite boundedness of the film form, and involve the audience in the problems opened up by the films. The problem of the ending of the work troubled Bertold Brecht as well, as he wrote in his epilogue to The good woman of Setzuan:

You're thinking, aren't you, that this is no right

Conclusion to the play you've seen tonight?

After a tale, exotic, fabulous,

A nasty ending was slipped up on

us. We feel deflated too. We too

are nettled

To see the curtain down and nothing

settled. How could a better ending be

arranged?

Could one change people? Can the world be changed? Would new gods do the trick? Will atheism?

Moral rearmament? Materialism?

It is for you to find a way, my

friends, To help good men arrive

at happy ends. You write the 
happy ending to the play!

There must, there must, there's got to be a way!

BRECHT 1966:141

Gotot's films generate uncertain endings to recognizable social conventions and narratives. These reversals clarify the hierarchy between cinema and its outside; the films prepare a swerve in the film's outside. As the epilogue to The good woman of Setzuan suggests, the production of drama is the first deed on this path, but it cannot, in itself, complete the task. The audience and their norms build the world.

This film practice of Gotot Prakosa was a redetermination of the hegemonic televisual and cinematic apparatus in the New Order. Gotot's practice rejected the constraints of governmental, documentary, and narrative cinema, which foreclosed, rather than beheld, the pedagogic potentiality of film. His film practice thus disarmed any master interpretative code as such. Its oblique aesthetic forms instead negated the ideological dispensations of the New Order that proclaimed to convey the univocal truth of images. In carrying out this practice, Gotot made cinema an element of actually existing democracy in the authoritarian conditions of the New Order. The name film pinggiran underscores the project to produce and circulate a displacement of sense-perception through film. Film pinggiran does not necessarily 'push the boundary' further away; instead, it makes the edge the manifest content itself.

\section{Acknowledgements}

Research for this article was funded by a Fulbright-Hays Doctoral Dissertation Research Abroad (DDRA) fellowship and the Graduate Division of the University of California, Berkeley. Earlier versions of this article were presented at the Methods Symposium of the Department of South and Southeast Asian Studies at the University of California, Berkeley as well as at the Obrolan Eksperimental workshop of the Rubanah Underground Hub in Jakarta. The author would in particular like to thank Sylvia Tiwon, Xin Liu, Gotot Prakosa (almarhum), Lisabona Rachman, Grace Samboh, and Jenny Zhang for their exceptionally insightful comments, which sharpened the focus of this article, as well as the two anonymous reviewers from $B K I$. The author would also like to thank the Faculty of Humanities at the University of Indonesia for their crucial support during the completion of this article. Finally, the author would like to thank Ibu Susi Natalia Prakosa and the estate of Gotot Prakosa, in conjunction with Amir Pohan of Buttonijo, who graciously allowed the images from Gotot's films to appear here. 


\section{References}

Achmadi, Heri (1979). 'Peringatan program normalisasi kehidupan kampus', KAMPUS: Karya dan Opini Inteligensia Muda (December) 1979.

Barker, Joshua (2005). 'Engineers and political dreams: Indonesia in the Satellite Age', Current Anthropology 45:703-27.

Biran, Misbach Yusa (2009). Sejarah film 1900-1950: Bikin film di Jawa. Jakarta: Komunitas Bambu.

Brecht, Bertold (1966). The good woman of Setzuan. New York: Grove Press.

Dhakidae, David (2003). Cendekiawan dan kekuasaan dalam negara Orde Baru. Jakarta: PT Gramedia.

Heeren, Katinka van (2012). Contemporary Indonesian film: Spirits of reform and ghosts from the past. Leiden: KITLV Press.

Heider, Karl G. (1991). Indonesian cinema. National culture on screen. Hawaii: University of Hawaii Press.

Heryanto, Ariel and Nancy Lutz (1988). 'The development of "development", Indonesia 46:1-24.

Jabrixs (2010). Dagelan mencla-mencle: Kumpulan humor dan pantun politik paling guueeer!!!. Jakarta: New Merah Putih.

Jameson, Frederic (2002). A singular modernity: Essay on the ontology of the present. London: Verso.

Kitley, Philip (200o). Television, nation, and culture in Indonesia. Athens: Ohio University Press.

Kusumaryati, Veronika (2013). 'Experimental filmmaking in New Order Indonesia', paper presented at the Conference on Critical Histories of Activism: Indonesia's New Order and its Legacies, University of California, Los Angeles, 14 April.

Mietzner, Marcus (2006). The politics of military reform in post-Suharto Indonesia: Elite conflict, nationalism and institutional resistance. Honolulu, HI: East-West Center.

Padmodarmaya, Pramana (ed.) (1994). 25 tahun Taman Ismail Marzuki.Jakarta:Yayasan Kesenian Jakarta.

Peransi, D.A. (1997). D.A. Peransi \& film. Jakarta: Lembaga Studi Film.

Prakosa, Gotot (1990). 'Interview with Gotot Prakosa', Cantrills Filmnotes 63/64:25-31.

Prakosa, Gotot (1997). Film pinggiran. Jakarta: Fakultas Film dan Televisi Institut Kesenian Jakarta \& YLP.

Prakosa, Gotot (2010). Animasi pengetahuan dasar film animasi Indonesia. Jakarta: Fakultas Film dan Televisi Insitut Kesenian Jakarta \& Yayasan Seni Visual Indonesia.

Prakosa, Gotot (2011). 'Poster film Indonesia', Jurnal Imaji 3:94-7.

Prakosa, Gotot (2012). 'Animation', presentation at the University of Minnesota, 14 March.

Prakosa, Gotot, Arswendo Atmowiloto and W.S. Rendra (2006). Kamera subjektif reka- 
man perjalanan dari sinema ngamen ke art cinema. Jakarta: Dewan Kesenian Jakarta dan Yayasan Seni Visual Indonesia.

Protschky, Susie (2011). Images of the tropics: Environment and visual culture in colonial Indonesia. Leiden: KITLV Press.

Riantiarno, Nano (1995). Semar gugat. Jakarta: Yayasan Bentang Budaya.

Robson, Stuart O. (ed.) (1969). Hikayat Andaken Penurat. The Hague: Nijhoff.

Said, Salim (1991). Shadows on the silver screen: A social history of Indonesian film. Jakarta: Lontar Foundation.

Sen, Krishna (1994). Indonesian cinema: Framing the New Order. London: Zed Books.

Supangkat, Jim (ed.) (1979). Gerakan seni rupa baru Indonesia. Jakarta: PT Gramedia.

Warwick, Donald (1986). 'The Indonesian family planning program: Government influence and client choice', Population and Development Review 12:453-9o.

Welker, Marina (2012). 'The Green Revolution's ghost: Unruly subjects of participatory development in rural Indonesia', American Ethnologist 39:389-406.

\section{Filmography}

Prakosa, Gotot (1999). Short films, videos, and animation works. Victoria, Australia: Between Three Worlds Video.

Prakosa, Gotot (1976a) (dir.). Meta meta. $16 \mathrm{~mm}$. Jakarta

Prakosa, Gotot (1976b) (dir.). Impuls. $16 \mathrm{~mm}$. Jakarta.

Prakosa, Gotot (1977) (dir.). Jalur. $16 \mathrm{~mm}$. Jakarta.

Prakosa, Gotot (1979) (dir.). A film about family planning. $16 \mathrm{~mm}$. Jakarta.

Prakosa, Gotot (1979) (dir.). Meta ekologi. $16 \mathrm{~mm}$. Jakarta.

Prakosa, Gotot (1983) (dir.). A ... Absolute ... Z ... Zen ...? 16 mm. Jakarta. 